\title{
A LAKOSSÁG SZEREPE A 20. SZÁZAD MÁSODIK FELÉNEK FELKELÉSELLENES MÜVELETEIBEN: A FRANCIA MEGKÖZELÍTÉS
}

\author{
DOI: $10.35926 /$ HSZ.2021.4.9
}

ÖSSZEFOGLALÁS: A 21. század elejének összetett biztonsági kihívásai növekvő bizonytalanságot eredményeznek és új konfliktusok irányába mutatnak. A konfliktusok egyre inkább olyan töréspontok mentén alakulnak ki, ahol a katonai és nem katonai eszközök egyidejü alkalmazásának változatos kombinációja jelenik meg. A konfliktusok alapvetően alacsony intenzitású, aszimmetrikus és irreguláris müveletei az ellenségeskedést az intézményi térből a társadalmi és az egyéni térbe helyezik át. A 20. század második felében Franciaország két olyan egymást követö, elhúzódó háborút is vívott, amelyekben a felkelésellenes müveletek társadalmi vonzatai meghatározók voltak. A jelentős áldozatokkal járó indokínai (1946-1954) és algériai (1954-1962) háborúkat azonban minden igyekezete ellenére sem nyerte meg. A tanulmányban a szerző két francia klasszikusnak, Roger Trinquiernek és David Galulának a lakosság háborúban betöltött szerepére vonatkozó gondolatait elemzi, megállapításai pedig egyértelmü figyelmeztetések a mai kor katonája számára. KULCSSZAVAK: biztonsági kihívások, felkelésellenes müveletek, társadalmi tér, indokínai háború, algériai háború, Roger Trinquier, David Galula

\section{STRATÉGIAI DOKUMENTUMOK}

Napjainkban a globális biztonsági környezet alapvető változásokon megy keresztül. A formálódó, többpólusúvá váló világrend alakulása, a nemzetközi szereplők kapcsolatait befolyásoló szabályok átalakítására való törekvés, a biztonsági kihívások összetettsége és folyamatos változása, azok egyre globálisabbá váló jellege, a technológiai forradalom hatásainak kiszámíthatatlansága növekvő bizonytalanságot eredményez. A biztonsági környezet kiszámíthatatlanságainak csillapításában meghatározók a NATO és az EU stratégiai dokumentumai, amelyeket Magyarország saját magára vonatkozóan irányadónak tekint. ${ }^{1}$

A magyar politikai érdekek érvényesítésének, az ország szuverenitása és területi egysége szavatolásának alapvető intézménye, fontos szereplöje a Magyar Honvédség, amely a haza védelme mellett aktívan hozzájárul a transzatlanti és az európai biztonság erősítéséhez.

A globális biztonsági környezet kihívásainak megfelelö kapacitások létrehozását, egyes megszünt kapacitások tudatos visszaépítését szolgálja a Magyar Honvédség átfogó, rendszerszintü fejlesztése, a Zrínyi Honvédelmi és Haderőfejlesztési Program. A program

1 1163/2020. (IV. 21.) kormányhatározat Magyarország Nemzeti Biztonsági Stratégiájáról, 1. sz. melléklet: Magyarország Nemzeti Biztonsági Stratégiája „Biztonságos Magyarország egy változékony világban”. Magyar Közlöny, CXLVII. évfolyam, 2020/81., 2101-2119. (a továbbiakban: NBS) 
eredményeként a Magyar Honvédség rövid figyelmeztetési időn belül reagálókésszé, békeidőben hiteles elrettentő erővé, válsághelyzetben vagy az Észak-atlanti Szerződés 5. cikke szerinti müvelet esetén hatékony védelmet és segítségnyújtást kifejteni képes haderővé fejlődik. Az átfogó haderőfejlesztés eredményeként a Magyar Honvédség a nemzetközi kötelezettségek és nemzeti feladatok végrehajtását támogató, regionális szinten is meghatározó fontosságú szereplővé válik.

Magyarország hibrid támadásokkal szembeni ellenálló képességét erősíti a honvédelmi és rendvédelmi erők szoros együttmüködése, valamint az információs és kiberhadviselést lehetővé tevő infokommunikációs rendszerek védelme. ${ }^{2}$

A globális biztonsági környezet jelentette kihívások ellenére Magyarország biztonsági helyzete jelenleg szilárd, azonban a kihívások folyamatos változása és intenzitása, a változások egyes tendenciái fokozatos romlást vetítenek előre. A válságok korai előrejelzés nélkül, gyorsan és számottevő figyelmeztetési idő nélkül alakulhatnak ki és terjedhetnek át. A konfliktusok kialakulása egyre inkább olyan töréspontok mentén foghatók meg a leginkább - mint a szimmetria/aszimmetria, alacsony/magas intenzitás, állami/nem állami szereplők, reguláris/irreguláris háború, hagyományos/hibrid hadviselés -, ahol a katonai és nem katonai eszközök egyidejü alkalmazásának változatos kombinációja jelenik meg. A töréspontoknál és azok környékén elmosódik a béke és a háború közötti éles határvonal, nehezen áttekinthető, háborús küszöb alatti, szürkezónás átmeneti állapotok jöhetnek létre.

A fennálló nemzetközi rend meggyengítésére és megváltoztatására törekvő állami és nem állami szereplők lehetőségeit a globalizáció nagymértékben felerősíti. Nem lehet figyelmen kívül hagyni a hagyományos konfliktusok kialakulásának vagy váratlan támadás bekövetkeztének a lehetőségét sem. Ez különösen veszélyes, mivel a globalizáció eredményeként a konfliktusok tér- és időbeli kirobbanásának, valamint jellegének előre jelezhetősége lecsökkent. A NATO jelentette kollektív védelem mellett ezért erősíteni kell az Európai Unió közös kül- és biztonságpolitikáját, a közös biztonság- és védelempolitikát pedig hatékonyabbá kell tenni. ${ }^{3}$

A Magyar Honvédség fejlesztésével párhuzamosan szükséges egy olyan hazai védelmi innovációs rendszer megteremtése, amely lehetővé teszi a védelmi tervezőrendszerek végrehajtási sebességének növelését, az innovatív fejlesztések gyors és szakszerü megvalósítását, valamint az ilyen megoldásoknak a haderőben történő elterjesztését. A haderőfejlesztés, a kutatás-fejlesztés, valamint a katonai felsőoktatás korszerüsítése eredményeként a Magyar Honvédség mind önállóan, mind szövetségi együttmüködésben képessé válik fegyveres agresszió elhárítására, valamint hibrid támadások kivédésére irányuló erőfeszítések támogatására. Politikai cél, hogy a Magyar Honvédség 2030-ra jól felszerelt és jól kiképzett erőkkel, rugalmas, hatékonyan alkalmazható, telepíthető és fenntartható, a szükséges mértékben interoperábilis képességekkel rendelkezzen.

A Magyar Honvédség korszerüsítése során alapvető fontossággal bír a nemzetközi környezetben megszerzett tudás és tapasztalat hasznosítása. Ez azért fontos, mivel hibrid támadásokra csak olyan haderö képes sikeres válaszokat adni, amelynek állománya magas

\footnotetext{
NBS, 2101-2105.

NBS, 2107-2112.; Jobbágy Zoltán: A felkelők elleni műveletekről: Egy elfeledett klasszikus: Bernardo de Vargas Machuca. Honvédségi Szemle, 141. évfolyam, 2013/2., 15. https://kiadvany.magyarhonvedseg.hu/index.php/ honvszemle/article/view/485; Porkoláb Imre: Szervezeti adaptáció a Magyar Honvédségben: Küldetésalapú vezetés 2.0 a digitális transzformáció korában. Honvédségi Szemle, 147. évf. 2019/1., 3-12. https://kiadvany. magyarhonvedseg.hu/index.php/honvszemle/article/view/205 (Letöltések időpontja: 2021. 05. 10.)
} 
színvonalú képzésben és kiképzésben részesült. A katonai felsőoktatás folyamatban lévő korszerüsítése, a nemzeti tisztképzés új rendszerének kialakítása során a nemzetközi környezetben megszerzett gyakorlati tapasztalatok feldolgozása, szakirodalommal való összevetése és megosztása továbbra is kiemelt fontossággal bír. ${ }^{4}$

A globális biztonsági környezet változásai eredményeként végrehajtandó műveletekre nagy valószínűséggel eltérő kultúrájú, megosztott társadalommal, visszamaradott infrastruktúrával és államszervezettel rendelkező országokban kerül sor. Mivel az ilyen műveleti környezetben kiemelt jelentőséggel bír a haderő megfelelő felkészítése és kiképzése a várható viszonyokra, különös figyelmet kell fordítani a Föld különbözö térségeiben, szintén eltérő kulturális és politikai viszonyok között, korábban szerzett tapasztalatok - különös tekintettel a lakossággal való megfelelő bánásmód - feldolgozására. ${ }^{5}$

A szimmetria/aszimmetria, alacsony/magas intenzitás, állami/nem állami szereplők, reguláris/irreguláris háború, hagyományos/hibrid hadviselés jelentette töréspontok mentén kirobbanó konfliktusok alapvetően alacsony intenzitású, aszimmetrikus és irreguláris müveletekben öltenek testet. Szélsőséges esetekben az ilyen jellegü müveletek az ellenségeskedést az intézményi térből a társadalmi térbe és az egyéni szférába helyezik át. Megjelenik bennük a terror és az ellenterror, valamint az ellenség teljes megsemmisítésének célja. A lakossággal való nem megfelelő bánásmód eredményeként az intézményi térből a társadalmi és az egyéni térbe átszivárgó erőszak abszolút jelleget ölthet. Ez a müveletek olyan hagyományos normákat kérdőjeleznek meg, mint a háború és a béke különválasztása, a katona és a civil megkülönböztetése, az ellenség és a bünöző elhatárolása, valamint az államok közötti és az államon belüli háború szétválasztása. A társadalmi és az egyéni tér előtérbe kerülése eredményezi a téridő hagyományos hadviseléstől eltérő értelmezését, a meglévő társadalmi struktúrák szétzúzását, a bel- és a külpolitikai kontextus összemosódását, valamint a hadviselést támogató technikai-ipari háttér megváltozását. ${ }^{6}$

Az alacsony intenzitású, aszimmetrikus és irreguláris müveletekben az egyik fél reguláris katonai szervezetek helyett kisebb csoportokban harcol, ezért a küzdelem kimenetelét nem néhány nagyobb csata, hanem nagyszámú kisebb összecsapás és egyéb tevékenység összessége és nem számszerüsíthető eredménye határozza meg. Az ilyen müveletek is valódi müveletek, de nem korlátozottak és nem hagyományosak. Nem korlátozottak, mivel nem csak katonák vesznek részt bennük és nem hagyományosak, mivel végrehajtásukat nem feltétlenül szabályozzák konvenciók, törvények és normák. Megvívásuk során ugyan érvényesek az alapvető hadműveleti elvek és megfontolások, de azok sok esetben különleges körülmények között és indirekt módon érvényesülnek, esetenként paradox módon jelentkeznek?

4 1656/2012. (XII. 20.) kormányhatározat Magyarország Nemzeti Katonai Stratégiájának elfogadásáról, 1. sz. melléklet: Magyarország Nemzeti Katonai Stratégiája. Magyar Közlöny, CXL. évfolyam, 2013/1., 21-28. (a továbbiakban: NKS).

NKS, 22-24.

${ }^{6}$ Carl Schmitt: The Theory of the Partisan: A Commentary/Remark on the Concept of the Political. Transl. A. C. Goodson. Michigan State University Press, 2004, 32-38. http://obinfonet.ro/docs/tpnt/tpntrex/cschmitt-theoryof-the-partisan.pdf. (Letöltés időpontja: 2014. 11. 20.)

7 Friedrich August Freiherr von der Heydte: Modern Irregular Warfare in Defense Policy and as a Military Phenomenon. New Benjamin Franklin House, London, 1986, 16-22.; Jobbágy Zoltán: David Galula és a felkelésellenes műveletek elmélete és gyakorlata francia megközelítésben. Hadtudományi Szemle, 10. évfolyam, 2017/4., 20-24.; Bakos Csaba Attila: Hagyományostól eltérő hadviselés, hagyományostól eltérő vezetésszemlélet. Társadalom és Honvédelem, 19. évf. 2015/3., 41-44.; AJP-3.4.4 (A) Allied Joint Doctrine for Counter-Insurgency, 2016, A-1 - A3. 


\section{FELKELÉSELLENES MÜVELETEK}

A szimmetria/aszimmetria, alacsony/magas intenzitás, állami/nem állami szereplők, reguláris/irreguláris háború, hagyományos/hibrid töréspontok mentén kirobbanó konfliktusok müveleteit a NATO szövetséges összhaderönemi kiadványai nem az 5. cikkely szerinti válságkezelö müveletekként, azon belül is felkelésellenes müveletként határozzák meg. ${ }^{8}$ A felkelésellenes müveletek mindennapjai nem ismeretlenek a Magyar Honvédség Irakban és Afganisztánban szolgált katonái számára. Az ilyen jellegü műveletek sajátosságainak jobb megértése érdekében az Amerikai Egyesült Államok szárazföldi hadereje 2006-ban a tengerészgyalogsággal közösen kiadta az FM 3-24 Counterinsurgency tábori kézikönyvet. A kidolgozásért felelős két tábornok, James N. Mattis és David H. Petraeus saját harctéri tapasztalataikra, valamint neves kutatók és jól felkészült törzstisztek munkáira támaszkodva egy kifejezetten olvasmányos, jól megírt és minden szempontból releváns kézikönyvet állítottak össze, amelyet 2014-ben kicsit más címmel és megújított tartalommal ismét kiadtak. ${ }^{9}$ Az FM 3-24-gyel összhangban 2011-ben a NATO is kiadta az AJP-3.4.4 Allied Joint Doctrine for Counter-Insurgency (COIN) szövetséges összhaderőnemi doktrínát, amelyet 2016-ban szintén követett egy átdolgozott változat. ${ }^{10}$

A felkelésellenes müveletek nem újak és nem ismeretlenek. Elötérbe kerülésük esetenként hangsúlyeltolódást és változásokat eredményez a katonai gondolkodásban, valamint a hadtudományban. Egyesek akár arra a következtetésre is juthatnak, hogy a hagyományos, államok által, hadseregek igénybevételével, politikai célokért megvívott háborúk kora lejárt. ${ }^{11}$ Példaként hozzák fel, hogy az atomháború rémével fenyegető globális szembenállás közel fél évszázada alatt a reguláris haderők mérete, valamint az államok költségvetéséből e haderőkre fordított összegek nagysága folyamatosan csökkent. A fejlett államok a jelenleginél sokkal nagyobb reguláris haderői ezért alig rendelkeztek a 20. század második felében szintén a szimmetria/aszimmetria, alacsony/magas intenzitás, állami/nem állami szereplők, reguláris/ irreguláris háború, hagyományos/hibrid hadviselés által meghatározott töréspontok mentén kirobbant konfliktusok alapvetően alacsony intenzitású, aszimmetrikus és irreguláris müveleteinek sikeres megvívásához szükséges képességekkel ${ }^{12}$

Az 1945-1990 között lezajlott mintegy 160 fegyveres konfliktus háromnegyede alacsony intenzitású, aszimmetrikus és irreguláris volt. Ezek a konfliktusok is a Föld kevésbé fejlett részein, eltérő kultúrájú, megosztott társadalommal, visszamaradott infrastruktúrával és államszervezettel rendelkező országokban robbantak ki. Ritkán vettek benne részt hagyományos hadseregek mindkét oldalon, a szemben álló felek által használt fegyverek pedig egyszerüek, sok esetben elavultak voltak. ${ }^{13}$ Alacsony intenzitásuk, aszimmetrikus és

\footnotetext{
${ }^{8}$ AJP-3.4 (A) Allied Joint Doctrine for Non-Article 5 Crisis Response Operations XX 20XX; AJP-3.4.4 (A) Allied Joint Doctrine for Counter-Insurgency, 2016.

${ }^{9}$ FM 3-24 Counterinsurgency. Department of the Army - Department of the Navy - U.S. Marine Corps, Washington, 2006; FM 3-24/MCWP 3-33.5 Insurgencies and Countering Insurgencies. Department of the Army, Washington, 2014; Lt. Col. John Nagl about "The U.S. Army/Marine Corps Counterinsurgency Field Manual". Book TV C-Span2, 2008. 12. 16. http://www.youtube.com/watch?v=QuDlrrRDfUw. (Letöltés időpontja: 2012. 10. 12.)

${ }^{10}$ AJP-3.4.4 (A) Allied Joint Doctrine for Counterinsurgency (COIN), 2011; AJP-3.4.4 (A) Allied Joint Doctrine for Counter-Insurgency, 2016.

${ }^{11}$ Martin van Creveld: The Transformation of War: The Most Radical Reinterpretation of Armed Conflict Since Clausewitz. The Free Press, New York, 1991.

${ }^{12}$ Creveld: i. m. 18-19.

${ }_{13}$ Uo. 20.
} 
irreguláris jellegük ellenére jelentős áldozatokkal jártak, rendkívül véresek tudtak lenni és komoly politikai eredmények elérését tették lehetővé. Az ilyen konfliktusok közelítik meg leginkább a Thomas Hobbes által felvázolt apokaliptikus (angolul Warre és nem War) háborút. ${ }^{14} \mathrm{~A}$ felkelésellenes mủveletekbe belebonyolódott fejlett nyugati országok a győzelem érdekében jelentős erőforrásokat mozgósítottak, a legjobb alakulataikat küldték harcba, a legfejlettebb haditechnikát alkalmazták, valamint sok esetben kifejezetten könyörtelenül bántak a helyi lakossággal. Ennek ellenére a gyarmataik nagy részét elvesztették, az évekig elhúzódó konfliktusok pedig jelentős erőforrásokat emésztettek fel. ${ }^{15}$

A többpólusúvá váló világrend változása, a technológiai forradalom kiszámíthatatlansága azt eredményezi, hogy a gazdag, erős, jelentős ipari háttérrel rendelkező fejlett országok egyre kevésbé képesek megnyerni ezeket a konfliktusokat. A felkelők sokszor alig rendelkeznek formális katonai kiképzettséggel, csoportjaik gyakran képtelenek egymással együttmüködni, vezetőiknek pedig szinte alig van lehetőségük zászlóaljnál nagyobb kötelék felett parancsnokolni.

A 20. század második fele óta eltelt időszak egyértelművé tette, hogy a felkelésellenes müveletek során a gazdag és fejlett országok reguláris hadereje a politikai érdekek érvényesítése szempontjából irreleváns és felettébb drága. ${ }^{16}$ Ez éles ellentétben áll a 19. század második felében lezajlott gyarmatosítási hullám katonai és politikai sikereivel. A gazdag, erős, jelentős ipari háttérrel rendelkező, fejlett országok hagyományos értelemben vett katonai mutatóiknak (felszerelés, fegyverzet, kiképzés, ellátás) köszönhetően egymás után arattak kisebb-nagyobb katonai győzelmeket. Az esetenkénti vereségektől függetlenül, technológiai és egyéb fölényüknek köszönhetően a gyarmatosítók kisebb haderői képesek voltak a legegyszerübb harceljárások alkalmazása esetén is a lényegesen nagyobb ellenséges erők felett sokszor mészárlásokba fulladó győzelmeket aratni.

Az elmúlt kétszáz év alacsony intenzitású, aszimmetrikus és irreguláris konfliktusai kimenetelének összehasonlítása egy veszélyes tendenciára világít rá. Az összesített kimutatás szerint ugyan a vizsgált időszakban az erősebb fél az esetek 70,8\%-ában diadalmaskodott, azonban amennyiben a kétszáz évet ötvenéves szakaszokra bontva vizsgáljuk, akkor már sokkal árnyaltabb kép rajzolódik ki. A kezdeti, 1800-1849 közötti időszakban az erősebb fél a konfliktusok 88,2\%-ban győzedelmeskedett. A következő, 1850-1899 közötti időszak során ez a fölény 79,5\%-ra csökkent, de továbbra is meghatározó maradt. Az 1900-1949 közötti időszakban az erősebb fél győzelme már csak az esetek 65,1\%-ára volt jellemző. Az 1950-1998 közötti időszakban ez a szám pedig már csak 45\%. ${ }^{17}$

E tendenciát a Magyar Honvédség szerepvállalásával is folyt iraki és afganisztáni háborúk csak tovább erösítik. A szimmetria/aszimmetria, alacsony/magas intenzitás, állami/nem állami szereplők, reguláris/irreguláris háború, hagyományos/hibrid hadviselés jelentette töréspontok mentén kirobbanó konfliktusok alacsony intenzitású, aszimmetrikus és irreguláris mủveletei, az egyre inkább a Nyugat (kereszténység) és a Kelet (iszlám) szembenállását jelentő terrorizmus elleni globális harc nem eredményezheti magától értetődően a hagyományos mutatók

14 Thomas Hobbes: Leviathan. Oxford University Press, Oxford, 1996, 84. Magyar fordítás: Leviatán vagy az egyházi és világi állam formája és hatalma. Ford. Vámosi Pál. Kossuth, Budapest, 2010, elektronikus dokumentum.

15 Creveld: i. m. 21-22.; R. Trinquier: Modern Warfare: A French View of Counterinsurgency. Praeger Security International, 2006.

${ }^{16}$ Creveld: i. m. 23-24; Azar Gat: War in Human Civilization. Oxford University Press, 2006, 622-657.

17 Ivan Arreguín-Toft: How the Weak Win Wars. A Theory of Asymmetric Conflict. International Security, Vol. 26, 2001/1., 96-99. 
alapján erősebb Nyugat győzelmét. A gyengébb fél tevékenységét átható vallásosság, amely a terrorizmus globális harcát szinte teljes egészében vallási tartalommal telíti meg, egy jellegét tekintve aszimmetrikus, dinamikáját tekintve alacsony intenzitású, belső tartalmát tekintve pedig irreguláris háborút a vallásháborúkra jellemző könyörtelenséggel itathat át. A vallási fanatizmus és az abból fakadó brutalitás egyértelmúvé teszi, hogy a kirobbanó konfliktusokban a Nyugat és szövetségesei számára a győzelem elérése nem egyszerü, még kevésbé egyértelmü. ${ }^{18}$

\section{FRANCIAORSZÁG HÁBORÚI}

A 20. század második felében Franciaország két olyan egymást követő, elhúzódó háborút is vívott, amelyekben az alacsony intenzitású, aszimmetrikus és irreguláris, azaz felkelésellenes müveletek voltak meghatározók. A jelentős áldozatokkal járó indokínai (1946-1954) és algériai (1954-1962) háborúkat Franciaország minden igyekezete ellenére sem nyerte meg. Az elsőben katonai és politikai vereséget szenvedett, a másodikat katonailag megnyerte, de politikailag elvesztette. A két háború magyar hadtudományi feldolgozása eddig csak részlegesen történt meg, a teljes körü feldolgozás egyelöre még várat magára. ${ }^{19}$

Az indokínai háború Észak-Vietnám (Tonkin), Közép-Vietnám (Annam), Dél-Vietnám (Kokinkína), valamint Kambodzsa és Laosz területén folyt, amelyek a 19. század óta mind francia gyarmatok vagy protektorátusok voltak. A második világháború alatti japán megszállást követöen Franciaország ismét igényt tartott e területekre. ${ }^{20}$ A területi függetlenségért folyó indokínai háborúban a francia erők folyamatosan megkísérelték a felkelőket a saját területükön legyőzni. A harcok zömében a két deltavidéken, valamint a központi partvidék egyes részein folytak. A franciák alapvető célja a vidéken élő falusi lakosság támogatásának megszerzése volt. Folyamatos küzdelmet folytattak a változó létszámú beszivárgott Việt Minh ügynökök semlegesítése, különböző löszer- és fegyverraktárak felszámolása, valamint a felkelök fegyveres csoportjainak megsemmisítése érdekében. A felkelésellenes müveletek során ezért központi szerepet játszott az utak és folyók szabad használatát biztosító összeköttetési vonalak feletti ellenörzés megszerzése, a francia szempontból fontosabb régiók feletti befolyás kiterjesztése, valamint a lakosság elégedetlenségének csillapítása és a felkelők lefegyverzése. ${ }^{21}$

A háború elején elért francia sikerek csak átmeneti jellegünek bizonyultak. A vereségek ellenére a Việt Minh nemcsak sikeresen védte reguláris erőit, de képes volt azokat növelni is. Az általa ellenőrzött vidéki területeken megerősítette jelenlétét, gerillakiképző központokat hozott létre és a sikeres gerillatevékenységnek köszönhetően nemcsak vissza tudta foglalni a kínai utánpótlás szempontjából fontos Việt Bắc tartomány egyes részeit, de Hà Nộitól (Hanoi) délre is üzemeltetett müveleti bázisokat. Ezt követően, immár kínai segítséggel,

${ }^{18}$ Creveld: i. m. 134-142.; Andrew W. Terrill: Controlling the Islamic State - Understanding the Strengths and Vulnerabilities of ISIS. Parameters, Vol. 44, 2014/3., 13-23.; Michael Hardt - Antonio Negri: Multitude: War and Democracy in the Age of Empire. Penguin Books, London, 2004, 4-25.

19 Harangi-Tóth Zoltán: A LEA-hadmüvelet. Hadtudomány, 38. évf. 2019/3., 59-70. DOI: 10.17047/HADTUD. 2019.29.3.59.

${ }^{20}$ Martin Windrow: The French Indochina War 1946-54. Osprey Publishing, Oxford, 1998, 59-70.

${ }^{21}$ Ronald J. Cima (ed.): Vietnam, a Country Study. Federal Research Division - Library of Congress, Washington, 1989, 54-56. 
teljesen kiszorította a franciákat a nevezett régióból, ezáltal képessé vált a Vörös-folyó deltájáig portyázni és lassan átvenni az ellenőrzést az ottani falvak fele felett. ${ }^{22}$

A következő években a Việt Minh célja a leggyengébb bázisok megtámadásával a francia erők kifárasztása, az ütközetek helyeinek maximális széthúzásával pedig a francia erők szétszórása volt, amely lényegében döntőnek bizonyult a háború kimenetele szempontjából. A felkelők tevékenységét elemezve a francia erők 1953-ban kinevezett parancsnoka, Henri Navarre tábornok különösen fontosnak tartotta a Việt Minh laoszi befolyásának megszüntetését. Ennek érdekében elfoglalta és megerősítette a határtól mintegy 16 kilométerre fekvő Điện Biên Phủt (Dien Bien Phu). A kisváros a Việt Minh számára is fontos volt a kínai határszakasz ellátási útvonalainak ellenőrzése miatt. Az összecsapásra mindkét fél felkészült, és 1954. március elejére a vietnámi oldalon 50 ezer katona, 55 ezer gerilla és 100 ezer szállítómunkás nézett szembe 15 ezer francia katonával. A mintegy két hónapig tartó és a franciák vereségével végződött csatában 25 ezer vietnámi és 1500 francia vesztette életét. ${ }^{23}$

A katonai vereség hatására Franciaország kénytelen volt lemondani korábbi befolyási területeiről, és a genfi tűzszüneti egyezmény aláírásával - amelynek eredményeként létrejött Észak- és Dél-Vietnám, valamint a független Laosz és Kambodzsa - végleg kivonult a térségből. ${ }^{24}$

Az indokínai háborút szinte azonnal követő algériai háború jellege kettős volt. Értelmezhető gyarmati háborúként a gyarmattartó Franciaország és a gyarmat Algéria között, de a franciabarát és a franciaellenes muszlim lakosság között folyó véres polgárháborúként is. A háborúban központi szerepet játszott a lakosság zömét képező muszlim őslakosok és a nagyjából annak egytizedét kitevő francia kisebbség megnyerése. ${ }^{25}$ Algéria helyzete egyedülálló volt Franciaország gyarmatai között, mivel az 1830-as megszállás óta három megyére felosztva - Texas és az Amerikai Egyesült Államok összekapcsolódásához hasonlóan - lényegében Franciaország részét képezte. Az anyaország lakosságától eltérően azonban a mintegy 9 millió algériai őslakosnak nem voltak politikai jogaik, és a gazdaság szinte teljesen a betelepült mintegy 1 millió francia kezében összpontosult. Az Algéria feletti francia hatalom fokozatos kiépülésének eredményeként viszont javult a lét- és közbiztonság, fejlödött a gazdaság, visszaszorították a betegségeket és emelkedett az írni-olvasni tudók aránya. A második világháború alatt 150 ezer algériai muszlim harcolt a franciák oldalán Tunéziában, Olaszországban, Franciaországban, azt követően pedig Indokínában. A francia kormányzatnak azonban soha nem volt bátorsága jobbítani a muszlim lakosság helyzetén. ${ }^{26}$ A második világháború befejezését ünnepelve, 1945. május 8-án összetüzésekre került sor a nyugat-algériai Sétifben az algériai zászlókat és szimbólumokat lengető tömeg, valamint a csendőrség között. Az összecsapásokat követő zavargásokban 103 francia telepes vesztette életét. A megtorlás brutális volt: a francia haderő szenegáli és szubszaharai katonáinak vérengzése következtében mintegy 15 ezer muszlim halt meg. A francia hatóságok közel tíz

${ }^{22}$ Cima: i. m. 57-58.; Bernard B. Fall: Street Without Joy: The French Debacle in Indochina. Stackpole Books, Mechanicsburg, 2018, 312-329.

23 Trinquier: i. m. 26-32.

${ }^{24}$ Kemény János: A vietnami kudarc hatása az amerikai felkelésellenes elméletre. Nemzet és Biztonság, 9. évf. 2016/6., 125.

${ }^{25}$ Martin Gilles: War in Algeria: The French Experience. Military Review, Vol. 83, 2005/3., 51.

${ }^{26}$ Matthew Connelly: A Diplomatic Revolution: Algeria's Fight for Independence and the Origins of the Post-Cold War Era. Oxford University Press, Oxford, 2002, 17-38.; Gilles: i. m. 51-52. 
évig próbálták a két közösség kapcsolatát normalizálni, kevés sikerrel. ${ }^{27}$ A helyzet a Nemzeti Felszabadítási Front ${ }^{28}$ 1954-es megalakításával drámaian megváltozott. Az alapítást követő hónapokban a militáns szervezet ellenállócsoportokat és városi sejteket hozott létre, tagokat toborzott, valamint a túlélésért küzdött. Az erőszak szintjének felemelésével gyülöletet és félelmet akart kelteni a muszlim és a francia lakosság között. Az egyre növekvő fanatikus erőszak kezelése, valamint a francia telepesek védelme miatt a francia haderő kénytelen volt a muszlim lakossággal szemben ellenőrzések, letartóztatások, kihallgatások, őrizetbe vétel formájában fellépni. Az NLF két év alatt kiterjesztette befolyását a muszlim lakosságra, és bár időközben a francia haderő létszáma 500 ezer före nőtt, nem tudta a helyzetet kezelni. A lázadók 1957-re képessé váltak robbantásos merényletekre a nagyobb városokban és magában a fővárosban, Algírban is. ${ }^{29}$

A francia kormány a haderőnek teljes felhatalmazást adott a rend helyreállítása érdekében. A haderő heteken belül felszámolta az NFL sejteket, főbb vezetőit megölte vagy más módon semlegesítette, és megkezdte az ország területének, határainak és lakosságának ellenőrzését. A kormány szerette volna a helyzetet politikailag rendezni és az ellenségeskedést tárgyalásos módon lezárni. Ez magára vonta az algériai francia lakosság mellett a katonák haragját is. A francia algériaiak 1958. május 13-án létrehozták a Közbiztonsági Tanácsot. ${ }^{30}$ A francia kormány a katonaságot kérte fel a tanács felszámolására. A haderő nem hajtotta végre a feladatot, sőt a Közbiztonsági Tanács oldalára állt. A hadsereg vezetői felszólították a kormányt a lemondásra, új alkotmányt és franciabarát Algéria-politikát követeltek, valamint De Gaulle államfői kinevezését. A helyzet odáig fajult, hogy a haderő egy Párizs elleni légideszant-müveletet is előkészített. Megkezdte emellett az algériai társadalom reformja keretében a muszlim lakosság egyenlővé tételét a francia telepesekkel, amelynek eredményeként a két közösség egymáshoz való közeledése ismét lehetővé vált. Az intézkedések hatására az NFL romokban hevert, létszáma mintegy 5000 főre csökkent. Nem volt képes támadó tevékenységet folytatni, lényegében a túlélésért harcolt. Mintegy 300 ezer muszlim pedig jelentkezett katonának a francia haderőbe. ${ }^{31}$

De Gaulle azonban, megértve az idők szavát, másképp döntött, és 1960 végén tárgyalásokba kezdett az NFL Tunéziában tartózkodó vezetőivel. A hadsereg vezetése tombolt, négy tábornok elfoglalta Algírt. A hadsereg zöme azonban most a kormány oldalán maradt, és 1962. március 16-án a kormány és az NFL aláírta a békeegyezményt. A francia algériaiak egy része, valamint a haderő radikális nézetet valló tagjai megalakították a Titkos Hadsereg Szervezetet ${ }^{32}$ azzal a céllal, hogy megöljék De Gaulle-t, kirobbantsanak egy polgárháborút a kormányzat, a rendőrség és a hadsereg ellen, valamint nyílt fegyveres harcot folytassanak a muszlimokkal és az NFL-lel szemben. A békeegyezmény aláírását követő hetek erőszakhullámának eredményeként rövid idő alatt egymillió algériai francia és franciabarát muszlim menekült Franciaországba. ${ }^{33}$

\footnotetext{
${ }^{27}$ Miquel Calçada: Analysis of the Algerian War of Independence or Les Événements: a Lost Opportunity for Peace. Journal of Conflictology, Vol. 3, 2012/2., 52-53.

${ }^{28}$ National Liberation Front - NLF (ang.); Front de libération nationale - FLN (fr.).

${ }^{29}$ Gilles: i. m. $52-53$.

${ }^{30}$ Itt ang. Committee for Public Safety; fr. Comité de Salut Public.

${ }^{31}$ Gilles: i. m. $53-54$.

${ }^{32}$ Secret Army Organization - SAO (ang.); Organisation de l'armée secrète - OAS (fr.).

${ }^{33}$ Uo. 54.
} 


\section{FRANCIA TEORETIKUSOK}

Az indokínai és algériai háborúk tapasztalatait feldolgozó francia és nemzetközi szakirodalom fősodrában két francia katonatiszt, Roger Trinquier (1908-1986) és David Galula (1919-1967) található. Mindketten hasonló módon dolgozták fel a két háború tapasztalatait és használták a felkelésellenes müveletek kifejezést. Trinquier sokak számára szélsőségesebb Galulánál, ami azonban nem feltétlenül igaz. Trinquier és Galula inkább kiegészítik egymást, és munkáikat együtt elemezve kapjuk meg a lakosság ilyen müveletekben játszott szerepét, illetve maguknak a felkelésellenes müveleteknek a lakosság által meghatározott dinamikáját. ${ }^{34}$

Trinquier szerint a felkelésellenes müveletekben a felkelők a lakosság felhasználásával képesek győzni. ${ }^{35}$ A győzelem a felkelök különböző politikai, gazdasági, pszichológiai és katonai szálakon futó, egymásba kapcsolódó cselekményeinek eredménye. A hagyományos értelemben vett katonai erőnek nincs döntő szerepe, mivel a katonai müveletek jelentősége a szembenállás során korlátozott. ${ }^{36}$ A lakosság központi szerepe miatt a szemben álló felek célja a lakosság feletti ellenőrzés és irányítás megszerzése.

A felkelésellenes erőnek képessé kell válnia a lakosság megvédésére és a lakosság önvédelemre történő felkészítésére, ugyanis a küzdelem a lakosságért folyik, amiben a lakosság is küzdő féllé válik, így fel kell készíteni a saját védelme megszervezésére. A lakosság militarizálása, a katonai és polgári vezetők kinevezése mind része ennek a folyamatnak. Energikus és intelligens vezetőket kell kiválasztani, akik néhány segítővel képesek védelmi szervezetek létrehozására. A vezetők feladata, hogy felosszák a közösséget körzetekre, a közösségek élén pedig alacsonyabb szintü vezetőket helyezzenek el saját segítőikkel. Az alacsonyabb szintü vezetők felosztják a körzeteket alkörzetekre, amely folyamat addig nem áll meg, amíg el nem éri a ház-/épület szintet. Ezt követően össze kell írni a lakosságot, majd népszámlálási kártyát (census card) kell kiállítani, amelynek eredményeként a mindenkori vezetők munkáját is figyelemmel lehet kísérni. Egy külön erre a célra létrehozott intézmény vagy hivatal pedig folyamatosan figyeli a közösség tagjaiból létrehozott védelmi szervezet tevékenységét. A védelmi szervezet jegyzékbe vett tagjai információval szolgálhatnak az ellenség rejtett behatolási kísérleteiről, esetenként segíthetnek azok felszámolásában is. ${ }^{37}$

A védelmi szervezet létrehozásával lehetővé válik az adott közösség életkörülményeinek megismerése, ami bizalmat ébreszthet a lakosságban a felkelésellenes erők iránt, az egyes szinteken megszervezett gyúlések pedig erősíthetik a minden irányú kapcsolatokat. A védelmi szervezet létrehozásával lényegében az egymás megértéséhez szükséges alapokat rakják le, ami a biztonság nélkülözhetetlen feltétele. Ezenfelül minél előbb létre kell hozni az egész országra kiterjedő hírszerző hálózatot. Lehetővé kell tenni, hogy a lakosság egy kisebb része még a védelmi szervezetek létrehozása előtt adatokkal szolgáljon a környezetükről, valamint olyan beépülésre kész ügynökökről, akik a felkelök első vonalát képezik. Az információ

34 Terrence Peterson: Myth-Busting French Counterinsurgency. War on the Rocks, 2015. 12. 03. https://waronthe rocks.com/2015/12/myth-busting-french-counterinsurgency/ (Letöltés időpontja: 2020. 12. 07.); Geoff Demarest: Let's Take the French Experience in Algeria Out of U.S. Counterinsurgency Doctrine. Military Review, Vol. 88, 2010/4., 19-21.

35 Trinquier: i. m. 38-42.; Demares: i. m. 22.

36 Trinquier: i. m. 44-48.; David Galula: Counterinsurgency Warfare: Theory and Practice. Praeger Security International, 2006, 20-24.

37 Trinquier: i. m. 27-31.; példaként említhető, hogy az ISAF a vezetők munkájának értékelésére Afganisztánban Joint Prioritized Shape and Influence Listet (JPSIL) és Joint Prioritized Effects Listet (JPEL) vezetett. 
biztosította lehetőségek gyors kihasználása mindennél fontosabb, ezért Trinquier javasolja egy hírszerző akciószolgálat felállítását is.

A felkelésellenes műveletek rendőrségi és propagandatevékenységgel járnak együtt. Ezt követi egy széles körü társadalmi program, amelynek célja a lakosság anyagi és morális támogatása a mindennapi élethez való gyors visszatérés érdekében. A rendőrségi müveleteket alapvetően rendőri erők hajtják végre, amely feladat azonban hárulhat a katonákra is. Ideális esetben a reguláris haderő a rendőri erők számára csak biztonsági hálót biztosít. A rendőri erők feladata a lakosság mielőbbi megszervezése és irányítása, egy tág értelemben vett hírszerző szolgálat létrehozása, valamint a már említett hírszerző akciószolgálat megteremtése.

Trinquier kiemeli, hogy a városokban a rendőri müveletek számos problémával járnak és esetenként kontraproduktív eredményt hozhatnak, ugyanis a felkelök minden eszközzel megpróbálják a rendfenntartó erők tevékenységét lassítani és megállítani, az elfogott ügynököket pedig egyszerü bűnözőként beállítani.

A felkelésellenes müveletek dinamikus része sürün lakott területen, nagyobb nyilvánosság bevonása mellett történik, amely éles ellentétben áll a hagyományos háború elkülönülő jellegétől. ${ }^{38}$ Fontos, hogy a lakosság tisztában legyen a modern háború céljával és eszközeivel, valamint a felkelésellenes erök elkötelezettségével megvédésüket illetően.

A rendőri müvelet befejezésével kap egyre nagyobb szerepet a békés rendezést szolgáló propaganda. ${ }^{39}$

A felkelőket csak a lakosság átállításával lehet meglepni és legyőzni. A lakossággal való együttmüködés lehetővé teszi a felkelők rejtett szervezeteinek sikeres, de legkevésbé sem látványos felszámolását, a tevékenységét biztosító alap szétrombolását. ${ }^{40} \mathrm{~A}$ felkelésellenes müveletek sajátossága, hogy a felkelésellenes erők nemcsak néhány fegyveres csoporttal állnak szemben, hanem egy lakosságba beépült, összetett szervezettel.

A felkelők szempontjából egy terület felosztható politikai-adminisztratív vezető által irányított városokra és lakossági központokra, politikai-katonai vezető által vezetett vidéki területekre, valamint szintén politikai-katonai vezető által vezetett menekülési/visszavonulási területekre. A legkívánatosabb a közbülső területek politikai-katonai vezetésének szétrombolása, amelyet a civil közigazgatás mentén kell megszervezni. Amennyiben szükséges, a népszámlálási kártyákat ki kell terjeszteni a nagyobb háziállatokra is, mert így ellenőrizhető az élelem és a haszonállatok mozgása.

A lakosság megszervezése saját védelme érdekében stratégiai falvak létrehozását teszi szükségessé. Amennyiben a stratégiai falvak biztonságos helyeknek számítanak és sikeresen müködnek, egyre többen kívánnak oda költözni. Így egyre több embert lehet ellenőrizni, vagyis egyre nyilvánvalóbbá válik, hogy kik a felkelők. Élelmiszerekhez jutásuk egyre nehezebbé válik és egyre jobban kiszorulnak egy adott területről.

Ezt követően indíthatók azok a projektek, amelyek a normális életmenet kialakítását és a gazdasági fellendülést szolgálják. Ide olyan tevékenységek tartoznak, mint az utak megjavítása, új utak építése, további stratégiai falvak kialakítása, valamint iskolák létrehozása. A lakosság megnyerése szempontjából fontos a pszichológiai tevékenység, valamint a hang-

38 Trinquier: i. m. 40-42.; AJP-01(E) Allied Joint Doctrine, 1-4 - 1.6; David Pion-Berlin - Miguel Carreras: Armed Forces, Police and Crime-fighting in Latin America. Journal of Politics in Latin America, Vol. 9, 2017/3., 3-26.

39 Trinquier: i. m. 45-50.; AJP-01(E) Allied Joint Doctrine, 4-2 és 4-6.

40 Trinquier: i. m. 50-52.; Schmitt: i. m. 48-52.; B. H. Liddell Hart: The Ratio of Troops to Space. Military Review, Vol. 38, 1960/4., 3-14.; Jim Gant: One Tribe at a Time. Nine Sisters Imports, Malibu, 2009, 14-15. 
szórók és a röplapok használata. A lakosság saját oldalra állításával a felkelésellenes erök finom hálót vetve halásszák ki a felkelőket és az őket támogató szervezet aktivistáit egy adott területen. Ez magas szintű és részletesen kidolgozott tervezői munkát igényel, amelyben a katonai szempontok mellett egyéb aspektusokat is figyelembe kell venni. ${ }^{41}$

A felkelésellenes müveletek során meg kell találni azokat a támogatókat, akik sikerrel tudják a lakosságot a felkelésellenes erők oldalára átbillenteni. Ennek érdekében megfelelő ismerettel kell rendelkezni a terület fizikai/földrajzi, gazdasági és emberi adottságairól, valamint a lakosság aktuális pszichológiai állapotáról. A lakossággal való kapcsolat kialakítását mindig kontaktcsoportok létrehozásával kell kezdeni, amelyeknek fele harcoló állomány, másik fele pedig egyenlő arányban kommunikációs szakember, illetve politikai és hírszerző ügynök. Alaprendeltetésük a helyi felkelők befolyásának megszüntetése, kiképzésük ideális esetben nem több három hónapnál. ${ }^{42}$

Galula szerint a felkelések alapvetően a helyi hatalmi viszonyokat megkérdőjelezve helyezik a meglévő közigazgatási, rendőri és katonai szerveket nyomás alá, ezért a lényeget tekintve a felkelések a polgárháborúval egyenlők. ${ }^{43}$ Az ilyen háborúban a felkelök és a felkelésellenes erök között aszimmetria áll fenn. A felkelők nem tudnak hagyományos értelemben cselekedni, ezért kénytelenek a konfliktust nem hagyományos módon kezelni. A legjobb eszköz erre a lakosság, amely a központi hatalomtól elidegeníthető, fizikailag ellenőrizhető és a felkelők számára aktív támogatást nyújthat. A lakosság központi szerepe miatt a felkelésellenes müveletek lényegében politikai tevékenységet takarnak. A politikai és a katonai tevékenység egy idő után nehezen válik különválaszthatóvá, azonban az elérendő katonai célokat mindig a politikai következmények mentén kell meghatározni, esetenként politikai céloknak alárendelni. ${ }^{44}$

A felkelések kirobbantásához a felkelőknek szükségük van egy egyszerü, közérthető és tartós okra. Megfogalmazásakor okosan kell összekapcsolni a különböző politikai, társadalmi, gazdasági, vallási és egyéb problémákat. A felkelök következő feladata, hogy egy alapvetően negatív okot párosítsanak össze bizonyos alkotó, építő elemekkel. Ezzel tudják bizonyítani, hogy nemcsak problémát fogalmaznak meg, hanem a megoldást is ismerik. ${ }^{45}$

Galula szerint a felkelésellenes müveleteknek vannak törvényei és vonatkozó elvei. Ezek közül az első törvény a lakosság támogatásának megszerzése, amely mindkét fél számára központi jelentőségü. A második törvény egy aktív támogató kisebbség megszerzése és mozgósítása propagandatevékenység céljából. Ezért tudnak a felkelések a legszemélyesebbek és egyben a legkegyetlenebbek is lenni.

A harmadik törvény: a lakosság központi szerepe miatt a győzelem sohasem lehet közvetlen, csak közvetett.

A negyedik törvény a lakosság támogatásának feltételessége, mivel hatékony politikai tevékenység nem képzelhető el a katonaság és a rendőrség egymás kölcsönös támogatása nélkül. Csak így tudják a felkelésellenes erők egyértelmủen bizonyítani, hogy rendelkeznek a

${ }^{41}$ Trinquier: i. m. 1-55.; AJP-01(E) Allied Joint Doctrine 2017; Farkas Sándor: Az ISIL hadviselése Mao Ce-tung tanainak tükrében: a kifárasztó gerilla-hadviselési forma. Honvédségi Szemle, 145. évf. 2017/2., 41. https:// kiadvany.magyarhonvedseg.hu/index.php/honvszemle/article/view/484; T. E. Lawrence: Seven Pillars of Wisdom. Wordsworth Editions, 1997, 363.; A hal-halász hasonlat ellentétpárjaként lásd Mao hal-víz hasonlatát: FMFRP 12-18., Mao Tse-Tung on Guerilla Warfare. Department of the Navy, Washington, 1961, 93.

42 Trinquier: i. m. 77-81.

43 Galula: i. m. 1-3.

44 Uo. 4-5.

45 Uo. 6. 
győzelem kivívásához szükséges akarattal, eszközökkel és képességekkel. Az ötödik törvény az erőkifejtés intenzitására és az eszközök mérhetetlenségére vonatkozik, mivel a felkelésellenes műveletek hosszú ideig húzódhatnak el és jelentős erőforrásokat emésztenek fel. ${ }^{46}$

A felkelésellenes mủveletek sikeres végrehajtásához a törvények mellett Galula hat elv betartását javasolja. Az első az erők gazdaságos alkalmazása, amelyre a műveletek térben és időben való elhúzódása miatt van szükség. A második a folyamatok visszafordíthatatlansága, amely miatt a felkelésellenes műveletek sok esetben sziszifuszi tevékenységet jelentenek. A harmadik a kezdeményezés, amely a felkelésellenes erők aktív, kezdeményező tevékenységének szükségességét helyezi előtérbe. A negyedik elv a képességek teljes körü alkalmazása. Ez azt jelenti, hogy a felkelésellenes erők a lakosság irányába végzett tevékenységük eredményeként rugalmassá válhatnak, és ezzel a hagyományos értelemben meglévő fölényük újra értelmet nyer. Az ötödik elv az egyszerüség, amelyre a felkelésellenes műveletek összetett jellege és bonyolultsága miatt van szükség. Fontos, hogy a felkelésellenes erök tagjai a feladataikat megértsék és a helyzetet átlássák. A hatodik elv a vezetés-irányításra vonatkozik. A felkelésellenes műveletek során, aki vezet, az egyben irányít és ellenőriz is. A vezetés-irányítás feladata, hogy a forradalmi háború véletlenszerü mozaikjait célirányos tevékenységgel szándékos mozaikmintává átalakítva a felkelőket egyre szűkebb korlátok közé terelje. ${ }^{47}$

A felkelésellenes müveletek tartalmaznak katonai, rendőri, valamint politikai feladatokat is. A katonai feladatok közé tartozik a gerillák kiüzése egy adott területről, visszatérésük megakadályozása, helyőrségek létrehozása, a lakosság védelme, valamint a fennmaradt gerillák felszámolása. A rendőri és bírói feladatok közé tartozik a felkelőerők politikai ügynökeinek elfogása, letartóztatása, kihallgatása, elítélése vagy esetleges felmentése. A politikai feladatok közé tartozik a lakossággal való kapcsolattartás, a helyi élet megszervezése, az infrastruktúra helyreállítása, javítása. Minden feladat egyformán fontos, ezért az egységes vezetés kiemelt fontosságú. Nincsenek csak katonai, csak rendöri, vagy csak politikai müveletek. A politikai megfontolások minden esetben, elvi és gyakorlati szinten is előnyt élveznek a katonaival szemben, mivel a katonai tevékenységek csak a politikai megfontolásokat figyelembe véve válnak értelmezhetővé. ${ }^{48}$

A felkelők legyőzése érdekében hadmüveleti szinten különböző tevékenységeket kell folytatni, amelyek során Galula nyolc lépést különböztet meg. Mindegyik lépésnek része a pszichológiai hadviselés propagandatevékenység keretében. A propagandatevékenység a felkelésellenes erők lakosság általi elfogadását, a lakosság megnyerését, valamint a felkelők gyengítését célozza meg.

Az első lépés a felkelőerők megsemmisítése vagy kiüzése egy adott területről, amely egyben a következő lépés előkészítését is szolgálja. Az első lépés akkor sikeres, ha a katonai erő lakosságot támogató és politikai tevékenységeket végrehajtó része biztonságosan tevékenykedhet. Fontos, hogy ez a lépés nem húzódhat el a jobb katonai eredmény elérése érdekében.

A második lépés a nem mozgékony egységek települése, amely során a felkelésellenes erők figyelme a lakosság felé helyeződik át. Cél egy olyan hálózat létrehozása, amely mind a lakosságnak, mind a felkelésellenes erők politikai csoportjainak megfelelö biztonságot nyújt.

${ }^{46}$ Uo. $7-12$.

${ }^{47}$ Uo. 49-60.

48 Jobbágy Zoltán - Czeglédi Mihály: Mission Command, Auftragstaktik és a szövetségi összhaderőnemi müveletek. Seregszemle, 14. évf. 2016/2., 86-90.; Charles W. Gwynn: Imperial Policing. Macmillan and Co., New York, 1934, 10-34.; Galula: i. m. 61-63. 
Ez a biztonságos keret teszi lehetővé a megfelelö kapcsolatok kialakítását a helyi lakossággal és vezetőikkel. Ekkor tudnak a katonák olyan, alapvetően civil feladatok végrehajtásában segíteni, amelyekkel a lakosság életét jobbá tehetik. A katonáknak a lakosság között kell élni és dolgozni annak érdekében, hogy mély és szoros kapcsolat alakuljon ki közöttük. ${ }^{49}$

A harmadik lépés a lakossággal való kapcsolatfelvétel és ellenőrzés megkezdése. Ennek célja a felkelésellenes erők lakosság feletti hatalmának helyreállítása, a lakosság elszigetelése a felkelöeröktől, valamint a szükséges hírszerzési tevékenység megkezdése a következő lépés előkészítése érdekében. Kapcsolatot kell kialakítani a lakossággal, őket népszámlálás keretében nyilvántartásba kell venni, meg kell szervezni védelmüket, el kell kezdeni a felkelökre vonatkozó információk gyüjtését, valamint meg kell nyerni a lakosság támogatását. A lépés sikere érdekében a felkelésellenes erőknek már gazdasági, társadalmi, kulturális és egészségügyi tevékenységeket is folytatniuk kell.

A negyedik lépés a felkelők politikai szervezeteinek szétzúzása, ügynökeik gyors és hatékony megsemmisítése. Ez akkor sikeres, ha a saját részröl minimális hibával, a lakosság részéről pedig minimális keserüséggel jár. Ez a lépés alapvetően rendőri feladatot jelent, mivel az ellenséges ügynökök esetenként köztiszteletben álló emberekként élik mindennapjaikat. Fontos szempont még, hogy a lakosság jelentős része tisztában van azzal, kik dolgoznak együtt a felkelőerőkkel. A felkelők ügynökeinek letartóztatása nagy odafigyelést és komoly szakértelmet, egyfajta közvetett megközelítést igényel. ${ }^{50}$

Az ötödik lépés a helyi választások megtartása, amely a felkelésellenes erők tevékenysége építő részének a kezdetét jelenti. Az eddigi lépések során sikerült a felkelök, valamint az ügynökök befolyását visszaszorítani, ezért a lakosság aktív támogatásának megszerzése a tét. A lakossági támogatás megszerzése érdekében helyi vezetőket kell választani, őket felelősséggel és hatalommal felruházni.

A hatodik lépés a megválasztott helyi vezetők tesztelése, képességeik felmérése. Tudatosítani kell bennük, hogy biztonságuk nagymértékben a lakosságtól és kevésbé a felkelésellenes erőktől függ. A helyi vezetöket a kezdeti támogatás után magukra kell hagyni, logisztikai és pénzügyi támogatást csak a szükséges mértékben indokolt számukra nyújtani.

A hetedik lépés egy párt megszervezése. Egy párt - a politika eszközeként - hatásosan tudja támogatni a felkelésellenes erők céljait és lehetővé teszi, hogy az őket támogató helyi vezetők regionális és országos szinten összekapcsolódjanak. Politikai párt létrehozásával a közigazgatási hatalom államigazgatási hatalommá válhat.

A nyolcadik, egyben utolsó lépés a megmaradt felkelők megnyerése vagy elnyomása a lakosság bevonásával. Ezzel a lépéssel a felkelésellenes erők a lakossággal közösen demonstrálják, hogy elkötelezettek a kialakult helyzet politikai rendezésére, az adott területen élő lakosság életének normalizálására. ${ }^{51}$

\footnotetext{
${ }^{49}$ Galula: i. m. 75-80.; a lépések száma és tartalma nagyjából megegyezik az AJP-3.4.4 által felsorolt ellentmondások (paradoxonok) számával, A-1 - A-3; Marsai Viktor: A szomáli szövetségi kormány első két éve és az al-Sabáb elleni katonai müveletek, 2012-2014 (I.). Nemzet és Biztonság, 8. évf. 2015/1., 86-94.

${ }^{50}$ Galula: i. m. $81-88$.

${ }^{51}$ Galula: i. m. 89-94.
} 


\section{ÖSSZEFOGLALÁS}

A tanulmány egyértelmủvé teszi, hogy a 20. század felkelésellenes müveleteinek francia a lakosság központi szerepet játszott. Ez valószínúleg nem lesz másképp a formálódó 21. század szimmetria/aszimmetria, alacsony/magas intenzitás, állami/nem állami szereplők, reguláris/ irreguláris háború vagy hagyományos/hibrid hadviselés jelentette töréspontok mentén kirobbanó és alapvetően alacsony intenzitású, aszimmetrikus és irreguláris sajátosságot mutató konfliktusainak felkelésellenes müveleteiben sem. A lakossággal való megfelelő kapcsolat kialakítása, a velük való együttmüködés rendjének megszervezése mindkét háborúban meghatározó elemét képezte a francia haderö felkelésellenes tevékenységének. A korlátlanná váló müveletekben a súlypontot képező lakosság a szemben álló felek érte folyó küzdelme miatt maga is küzdő féllé vált. A francia haderő felkelésellenes müveletei a háborút kiléptették intézményes kereteiböl és annak összes borzalmát „betolták” a lakosság mindennapjaiba. A Hobbes által felvázolt apokaliptikus háború Indokínában és Algériában a lakosság jelentős része számára valósággá vált. A lakosság felkelésellenes müveletekbe való közvetett és közvetlen bevonása francia részről mindig normatív volt, mivel meg kellett találni azokat az aktív támogatókat, akik sikerrel tudták a lakosságot a franciák oldalára átbillenteni.

A katonai, rendőri, valamint politikai feladatokat ennek megfelelően egységes vezetés alatt össze kellett hangolni, mindez megkövetelte a gazdasági, a társadalmi és a kulturális tényezők ismeretét. A felkelésellenes erőknek ezért mindkét háborúban megfelelő ismerettel kellett rendelkezniük egy adott terület fizikai, földrajzi, gazdasági és emberi adottságairól, valamint a lakosság aktuális pszichológiai állapotáról. A lakossággal való együttműködés olyan nem kifejezetten katonai tevékenységeket is megkövetelt, amelyek a normális életmenet kialakítását és a gazdasági fellendülést szolgálták. A siker érdekében a franciák olyan széles körü társadalmi programokat indítottak el, amelynek célja a lakosság anyagi és morális támogatása volt a mindennapi életmenethez való gyors visszatérés érdekében. Az átfogó megközelítés és a győzelem közvetett módon lehetséges kivívása miatt ezek a háborúk hosszú ideig húzódtak el és jelentős erőforrásokat emésztettek fel. Franciaország minden katonai és politikai szándéka ellenére sem érte el stratégiai céljait. A műveletek során esetenként megnyilvánuló katonai brutalitás, azok egyes fázisait kísérö politikai erkölcstelenség komoly belpolitikai válságot okozott Franciaországban. A háborúkat, különösen az algériai háborút lezáró véres leszámolások pedig egyértelmüsítették a társadalmi és az egyéni tér előtérbe kerülésével járó súlyos következményeket. Ez mindenképpen legyen figyelmeztetés a mai kor katonája számára.

\section{FELHASZNÁLT IRODALOM}

1163/2020. (IV. 21.) kormányhatározat Magyarország Nemzeti Biztonsági Stratégiájáról, 1. sz. melléklet: Magyarország Nemzeti Biztonsági Stratégiája „Biztonságos Magyarország egy változékony világban”. Magyar Közlöny, CXLVII. évfolyam, 2020/81., 2101-2119.

1656/2012. (XII. 20.) Korm. határozat Magyarország Nemzeti Katonai Stratégiájának elfogadásáról,

1. sz. melléklet: Magyarország Nemzeti Katonai Stratégiája. Magyar Közlöny, CXL. évf. 2013/1., 21-28.

AJP-01(E) Allied Joint Doctrine, 2017.

AJP-3.4 (A) Allied Joint Doctrine for Non-Article 5 Crisis Response Operations, XX 20XX.

AJP-3.4.4 (A) Allied Joint Doctrine for Counter-Insurgency (COIN), 2011. 
AJP-3.4.4 (A) Allied Joint Doctrine for Counter-Insurgency, 2016.

Arreguín-Toft, Ivan: How the Weak Win Wars: A Theory of Asymmetric Conflict. International Security, Vol. 26, 2001/1., 93-128.

Bakos Csaba Attila: Hagyományostól eltérö hadviselés, hagyományostól eltérö vezetésszemlélet. Társadalom és Honvédelem, 19. évf. 2015/3., 41-52.

Calçada, Miquel: Analysis of the Algerian War of Independence or Les Événements: a Lost Opportunity for Peace. Journal of Conflictology, Vol. 3, 2012/2., 52-61.

Cima, Ronald J. (ed.): Vietnam, a Country Study. Area Handbook Series. Federal Research Division Library of Congress, Washington, 1989.

Connelly, Matthew: A Diplomatic Revolution: Algeria's Fight for Independence and the Origins of the Post-Cold War Era. Oxford University Press, Oxford, 2002.

Creveld, Martin van: The Transformation of War: The Most Radical Reinterpretation of Armed Conflict since Clausewitz. The Free Press, New York, 1991.

Demarest, Geoff: Let's Take the French Experience in Algeria Out of U.S. Counterinsurgency Doctrine. Military Review, Vol. 88, 2010/4., 19-24.

Ellis, John: The Social History of the Machine Gun. Pantheon Books, New York, 1975.

Fall, Bernard B.: Street Without Joy: The French Debacle in Indochina. Stackpole Books, Mechanicsburg, 2018.

Farkas Sándor: Az ISIL hadviselése Mao Ce-tung tanainak tükrében: a kifárasztó gerilla-hadviselési forma. Honvédségi Szemle, 145. évf. 2017/2., 38-46. https://kiadvany.magyarhonvedseg.hu/ index.php/honvszemle/article/view/484.

FM 3-24 Counterinsurgency. Department of the Army - Department of the Navy - U.S. Marine Corps, Washington, 2006.

FM 3-24/MCWP 3-33.5 Insurgencies and Countering Insurgencies. Department of the Army, Washington, 2014.

FMFRP 12-18, Mao Tse-Tung on Guerilla Warfare. Department of the Navy, Washington, 1961.

Galula, David: Counterinsurgency Warfare: Theory and Practice. Praeger Security International, 2006. Gant, Jim: One Tribe at a Time. Nine Sisters Imports, Malibu, 2009.

Gat, Azar: War in Human Civilization. Oxford University Press, Oxford, 2006.

Gilles, Martin: War in Algeria: The French Experience. Military Review, Vol. 83, 2005/3., 45-57.

Gwynn, Charles W.: Imperial Policing. Macmillan and Co., New York, 1934.

Harangi-Tóth Zoltán: A LEA-hadmüvelet. Hadtudomány, 38. évf. 2019/3., 59-70. DOI: 10.17047/ HADTUD.2019.29.3.59.

Hardt, Michael - Negri, Antonio: Multitude: War and Democracy in the Age of Empire. Penguin Books, London, 2004.

Heydte, Friedrich August Freiherr von der: Modern Irregular Warfare in Defense Policy and as a Military Phenomenon. New Benjamin Franklin House, London, 1986.

Hobbes, Thomas: Leviathan. Oxford University Press, Oxford, 1996. Magyarul: Hobbes, Thomas: Leviatán vagy az egyházi és világi állam anyaga, formája és hatalma. Ford. Vámosi Pál. Magyar Helikon - Európa, Budapest, 1970.

Jobbágy Zoltán: A felkelők elleni műveletekről: Egy elfeledett klasszikus: Bernardo de Vargas Machuca. Honvédségi Szemle, 141. évf. 2013/2., 15-18. https://kiadvany.magyarhonvedseg.hu/index.php/ honvszemle/article/view/485

Jobbágy Zoltán: David Galula és a felkelés ellenes müveletek elmélete és gyakorlata francia megközelitésben. Hadtudományi Szemle, 10. évf. 2017/4., 82-97.

Jobbágy Zoltán - Czeglédi Mihály: Mission Command, Auftragstaktik és a szövetségi összhaderönemi müveletek. Seregszemle, 14. évf. 2016/2., 86-94. 
Kemény János: A vietnami kudarc hatása az amerikai felkelésellenes elméletre. Nemzet és Biztonság, 9. évf. 2016/6., 121-142.

Lawrence, T. E.: Seven Pillars of Wisdom. Wordsworth Editions, 1997. Magyarul: Lawrence, T. E.: Lázadás a sivatagban. Ford. Schöpflin Aladár. Új Géniusz, Budapest, 1990.

Liddell Hart, B. H.: The Ratio of Troops to Space. Military Review, Vol. 38, 1960/4., 3-14.

Lt. Col. John Nagl about "The U.S. Army/Marine Corps Counterinsurgency Field Manual". Book TV C-Span2, 2008. 12. 16. http://www.youtube.com/watch?v=QuDlrrRDfUw

Marsai Viktor: A szomáli szövetségi kormány elsö két éve és az al-Sabáb elleni katonai müveletek, 2012-2014 (I.). Nemzet és Biztonság, 8. évf. 2015/1., 65-95.

Peterson, Terrence: Myth-Busting French Counterinsurgency. War on the Rocks, 2015. 12. 03. https:// warontherocks.com/2015/12/myth-busting-french-counterinsurgency/

Pion-Berlin, David - Carreras, Miguel: Armed Forces, Police and Crime-fighting in Latin America. Journal of Politics in Latin America, Vol. 9, 2017/3., 3-26.

Porkoláb Imre: Szervezeti adaptáció a Magyar Honvédségben: küldetésalapú vezetés 2.0 a digitális transzformáció korában. Honvédségi Szemle, 147. évf. 2019/1., 3-12. https://kiadvany.magyar honvedseg.hu/index.php/honvszemle/article/view/205

Schmitt, Carl: The Theory of the Partisan: A Commentary/Remark on the Concept of the Political. Transl. A. C. Goodson. Michigan State University Press, 2004, 32-38. http://obinfonet.ro/docs/ tpnt/tpntrex/cschmitt-theory-of-the-partisan.pdf

Terrill, Andrew W.: Confronting the Islamic State - Understanding the Strengths and Vulnerabilities of ISIS. Parameters, Vol. 44, 2014/3., 13-23.

Trinquier, R.: Modern Warfare: A French View of Counterinsurgency. Praeger Security International, 2006.

Windrow, Martin: The French Indochina War 1946-54. Osprey Publishing, Oxford, 1998. 